\title{
Iron doses in the production of potted rosebushes
}

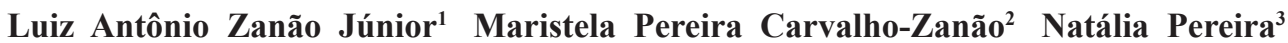 \\ José Antônio Saraiva Grossi ${ }^{4}$ Reginaldo Ferreira Santos ${ }^{3}$
}

\begin{abstract}
'Instituto Agronômico do Paraná, 85825-000, Santa Tereza do Oeste, PR, Brasil. E-mail: lzanao@iapar.br. "Corresponding author.
${ }^{2}$ Departamento de Pós-graduação em Agronomia, Universidade Estadual do Oeste do Paraná (UNIOESTE), Marechal Cândido Rondon, PR. Brasil. ${ }^{3}$ Departamento de Pós-graduação em Engenharia de Energia na Agricultura, Universidade Estadual do Oeste do Paraná (UNIOESTE), Cascavel, PR, Brasil. ${ }^{4}$ Departamento de Fitotecnia, Universidade Federal de Viçosa (UFV), Viçosa, MG, Brasil.
\end{abstract}

\begin{abstract}
The production and quality of roses are influenced by fertilization management. The aim of this experiment was to evaluate the effects of doses of iron ( $\mathrm{Fe}$ ) in the production of potted rose bushes (Rosa hybrida). Treatments were based on five doses of Fe (0, 1 , 3, 5 and $15 \mathrm{mg} \mathrm{kg}^{-1}$ ) applied on the substrate, in a randomized block design with four replications. Seedlings presented two pairs of leaves and were individually transplanted into plastic pots $\left(0.8 \mathrm{dm}^{3}\right)$ containing commercial substrate. Each experimental plot consisted of a vase with a plant with two flower stalks. The following parameters were evaluated: number of leaves and flowers per flower stalk; dry matter production of roots, leaves and flowers; plant height and diameter and floral longevity. In addition, foliar levels of total chlorophyll and Fe were determined. Fertilization with Fe increases the production and quality of flowers of the rosebush cv. 'Shiny Terrazza, ${ }^{\circledR}$. Dose of Fe to be added to the substrate used in this study for maximum economic efficiency for this cultivar is $3.6 \mathrm{mg} \mathrm{kg}^{-1}$.
\end{abstract}

Key words: Rosa hybrida, floriculture, plant nutrition.

Doses de ferro na produção de roseiras de vaso

RESUMO: A produção e qualidade das rosas são influenciadas pelo manejo da adubação. Objetivou-se com este experimento, avaliar os efeitos de doses de ferro ( $\mathrm{Fe}$ ) na produção de roseiras (Rosa hybrida) cultivadas em vasos. Os tratamentos foram constituidos de cinco doses de Fe (0, 1, 3, 5 e 15 $\left.\mathrm{mg} \mathrm{kg}^{-1}\right)$ aplicadas no substrato, em delineamento de blocos casualizados, com quatro repetições. As mudas apresentavam dois pares de folhas e foram individualmente transplantadas para vasos plásticos $\left(0,8 \mathrm{dm}^{3}\right)$ contendo substrato comercial. Cada parcela experimental foi constituida por um vaso com uma planta com duas hastes florais. Foram avaliados a quantidade de folhas e flores por haste floral; produção de matéria seca de raizes, folhas eflores; altura das plantas e diâmetro e, longevidade floral. Além disso, foram determinados os teores foliares de clorofila total e Fe. A adubação com Fe aumenta a produção e a qualidade das flores da roseira cv. 'Shiny Terrazza' ${ }^{\circledR}$. dose de Fe a ser adicionada a substrato para obtenção da máxima eficiência econômica para essa cultivar é 3,6mg $\mathrm{kg}^{-1}$.

Palavras-chave: Rosa hybrida, floricultura, nutrição de plantas.

\section{INTRODUCTION}

Floriculture in Brazil has been expanding, gaining quality, competitiveness and branching out in all regions of the country (JUNQUEIRA \& PEETZ, 2014). Within the agribusiness it represents an important economic activity. Since 2006 the flower sector has been registering a growth of 5 to $8 \%$ in volume and of 4 to $7 \%$ in value (INSTITUTO BRASILEIRO DE FLORICULTURA, 2015). In the production of cut flowers, the rose stands out as the most consumed, with about 180 million stems commercialized per year (MARTINS et al., 2009; BARGUIL et al., 2010).

An important factor in the cultivation of roses, to obtain higher productivity and better quality, is the proper mineral nutrition of plants (SAVVAS, 2002). Metabolic imbalance that can be expressed in the plant's characteristics is caused by the deficiency or excess of mineral elements, essential to their development (TAIZ \& ZAIGER, 2010).

Micronutrients interfere in the quality of flowers, which is related to their physical properties, which determine the appearance of the plants. Adequate supply of these nutrients is vital to achieve the standards of commercialization and consumption (FURTINI NETO et al., 2015).

$\mathrm{Fe}$ is usually the micronutrient absorbed in higher quantities by the plants, being, involved in several physiological processes of the plants and an important component of enzymes responsible for transfer of 
electrons in chloroplasts and mitochondria. It plays a major role in cellular respiration, photosynthesis, synthesis of chlorophyll, lignin and carbohydrates, and reduction of nitrite and sulfite (EPSTEIN \& BLOOM, 2004; KAMBLE et al., 2014). Both its deficiency as its excess may harm the development of crops.

The rose has the ability to uptake large amounts of soil nutrients, especially Fe, which is the micronutrient uptaken in greater quantities by many cultivars of this ornamental plant (VILLAS BÔAS et al., 2008; ZANÃO JÚNIOR et al., 2013). Fe is important in maintaining the quality of plants. Although it is reported in abundance in nature, plants can not easily absorb Fe due to its low solubility in the soil (AREF, 2012). Therefore Fe can be a limiting factor for crops and should be provided in appropriate quantity and forms.

The Fe deficiency in plants generates the characteristic symptom of internerval chlorosis in young leaves and could evolve into necrosis in extreme deficiency conditions (BRIAT et al., 2007). DUTRA (2009) verified these symptoms in rosebushes. The toxicity caused by an excess of $\mathrm{Fe}$ in the metabolism of the plant causes an orange color in the older leaves and chlorosis in younger leaves at more advanced stages (FAGERIA \& BARBOSA FILHO, 2006). Thus, in ornamental species, where the good quality of the product is as important as productivity, it is essential to determine the appropriate dose of Fe to be applied.

The effect of $\mathrm{Fe}$ in the fertilization of ornamental species of economic interest as the rose, as well as the provision of appropriate dose for quality production, motivates studies on the issue. Thus, the aim of this study was to evaluate the effect of Fe doses in the production and quality of roses (Rosa hybrida) grown in pots.

\section{MATERIALS AND METHODS}

The experiment was conducted in a greenhouse in the period from October to December. The average daily minimum and maximum temperatures were 17.3 and $33.9^{\circ} \mathrm{C}$, respectively, and the variations of the diurnal and nocturnal relative air humidity averages were 65.6 and $85.5 \%$, respectively. The cultivar of the rosebush evaluated was Shiny Terrazza ${ }^{\circledR}$, that features yellow flowers. Seedlings with two pairs of leaves were individually transplanted to plastic pots with a capacity of $0.8 \mathrm{dm}^{3}$, with commercial substrate Plantmax ${ }^{\circledR}$, formulated with pine bark, peat and vermiculite. After transplanting and acclimatization of the seedlings in the greenhouse, pruning was proceeded. Irrigation was performed daily and fertirrigation twice a week using $50 \mathrm{~mL}$ of a solution of macro and micronutrients (no $\mathrm{Fe}$ ) per vase recommended for ornamental flowers. The nutrients supplied by the nutrient solution (ZANÃO
JÚNIOR et al., 2013) during the experiment were (mg kg-1 in the substrate): $200 \mathrm{~N} ; 350 \mathrm{P} ; 150 \mathrm{Ca} ; 100 \mathrm{Mg} ; 80 \mathrm{~S} ; 1.2$ B; $0.5 \mathrm{Cu} ; 1.5 \mathrm{Mn} ; 0.1 \mathrm{Mo}$ and $1 \mathrm{Zn}$.

The soluble and total content of $\mathrm{Fe}$ in the substrate were evaluated by the Dutch method 1:1,5 by means of water extraction (SONNEVELD \& ELDEREN, 1994), with Fe determination by plasma optical emission spectrometry (ICP-OES) (Perkin Elmer, Optima 3300DV). A content soluble and total Fe of $0.1 \mathrm{mg} \mathrm{L}^{-1}$ and $5 \mathrm{mg} \mathrm{kg}^{-1}$, were respectively verified.

The plants were treated with five doses of Fe$\operatorname{EDTA}\left(0,1,3,5\right.$ and $\left.15 \mathrm{mg} \mathrm{kg}^{-1}\right)$, applied on the substrate, in a randomized block design with four replications. The source used was ferrous ammonium sulfate $(29 \%$ Fe, Vetec, 99.5\% purity), along with EDTA (Synth, $99.9 \%$ purity). EDTA form a stable complex with the metal across a $\mathrm{pH}$ range from 4.0 to 6.3 (ALBANO \& MILLER, 2001). Each experimental plot consisted of a vase with a plant with two flower stalks.

Fe was added to the substrate in a single application after pruning, when the sprouting reached about $10 \mathrm{~cm}$, with at least one leaf expanded by stem.

To evaluate the floral opening stage the scale proposed by CUSHMAN et al. (1994) was adopted, with the following figures for the stages: 1 for closed flower bud; 2 for closed petals and open sepals; 3 for the start of opening of the petals (traditional flower bud stage); 4 for several open petals; 5 to fully open flower bud; and 6 for the end of the flower vase life (more than one wilted and/or darkened petal).

In stage 2 of floral opening, the plant height (measured from the top edge of the vase to the end of the flower bud) and the number of leaves and flowers per floral stem were evaluated.

Floral longevity was determined by the number of days between stage 2 and stage 6 of floral opening. The determination of the total chlorophyll leaf content was performed by the colorimetric method described by PORRA et al. (1989). For this purpose, leaf discs of the $4^{\text {th }}$ pair of leaves from the apex were collected in stage 6 of flower opening (flowers senescence).

Discs $\left(1.414 \mathrm{~cm}^{2}\right)$ were collected between the secondary ribs excluding the main rib, immersed in $25 \mathrm{~mL}$ acetone solutions $\left(800 \mathrm{~mL} \mathrm{~L}^{-1}\right)$ and placed in the dark for four days, at the average temperature of $3^{\circ} \mathrm{C}$. Chlorophyll content was determined by reading the absorbances of the extracts at the wavelengths of 645 and $663 \mathrm{~nm}$ on a spectrophotometer (Shimadzu, UV mini-1240). Calculation used to quantify the pigment was: Total chlorophyll $(\mathrm{a}+\mathrm{b})=17,76 \mathrm{~A}^{645}+7,34 \mathrm{~A}^{663}$, where: $\mathrm{A}^{663}=$ absorbance at $663 \mathrm{~nm} ; \mathrm{A}^{645}=$ absorbance at $645 \mathrm{~nm}$.

The number of leaves and flowers per floral stem was determined by counting only the open flowers 
and leaves with five leaflets or more. The diameter of the flowers was evaluated in stage 5 of floral opening and dry matter production of flowers on stage 6 of floral opening.

Leaves, flowers and roots were detached from the plant, washed with distilled water, dried in a forced-air oven at $65^{\circ} \mathrm{C}$ until constant weight, in order to determine the dry matter. Leaves were ground in a Wiley mill with a $0.84 \mathrm{~mm}$ screen and mineralized by a mixture of nitric and perchloric acids $\left(3: 1 \mathrm{v} \mathrm{v}^{-1}\right)$ for the determination of $\mathrm{Fe}$ content by atomic absorption spectrophotometry (GBC, model 908 AA) (JONES JÚNIOR et al., 1991).

The data were submitted to analysis of variance. Regression equations were adjusted for the evaluated variables in function of Fe doses, with the coefficients tested to $5 \%$ probability by the $F$ test. Models tested for the studied variables were: linear, quadratic root, quadratic and cubic. The models were chosen based on the significance of the regression coefficients, on biological significance and determination coefficient.

For the calculation of dry matter production of flowers at maximal economic efficiency, a dose equivalent to $95 \%$ of the maximum physical production was used (ALVAREZ, 1996).

\section{RESULTS AND DISCUSSION}

The Fe doses did not influence plant height (Figure 1a), number of leaves (NLFL, Figure 1C) and flowers per floral stem (NFFS, Figure 2C), floral longevity (Figure 2D) and foliar chlorophyll levels (Figure 1E). The dry matter production of roots (DMPR, Figure 1B), leaves (PDML, Figure 1D) and flowers (DMPF, Figure 2B) and floral diameter (Figure 2A) were influenced by Fe doses and followed a quadratic model at increasing $\mathrm{Fe}$ doses while the foliar levels of Fe, followed a linear model regression.

The average plant height was $20.71 \mathrm{~cm}$ and the average number of leaves 9.25 per flower stem. Working with the same cultivar of rosebush and evaluating doses of B, ZANÃO JÚNIOR et al. (2014) verified average heights of the plants close to this value. They also verified that higher doses of $\mathrm{B}$ caused a reduction in the number of leaves per flower stem, because of toxicity effects caused by an excess of this micronutrient. AHMAD et al. (2010) verified that the foliar application of $\mathrm{Fe}$ in rosebushes also did not cause a high growth of the plants. However, the authors observed a positive response when the application of Fe was combined with more than one micronutrient, as observed by KHOSHGOFTARMANESH et al. (2008).

There was a significant positive response to the $\mathrm{Fe}$ doses in the dry matter production of roots and leaves of rosebushes and the application of $7.75 \mathrm{mg}$ $\mathrm{kg}^{-1} \mathrm{Fe}$ provided the highest results of maximum dry matter production of leaves and $9.45 \mathrm{mg} \mathrm{kg}^{-1} \mathrm{Fe}$ a maximum dry matter production of roots (Figures $1 \mathrm{~b}$ and 1d). DUTRA (2009) verified that the Fe omission in rosebush cultivation (cv. Vegas) caused a smaller dry matter production of leaves and roots. According to KAMBLE et al. (2014) Fe is involved in respiration, chlorophyll synthesis, carbohydrate production and also in leaf development, thereby justifying the observed results. Above the $9.45 \mathrm{mg} \mathrm{kg}^{-1}$ of $\mathrm{Fe}$ there was a reduction in the production of dry matter in leaves and roots. SANTOS et al. (2011) verified that high doses of $\mathrm{Fe}$ in nutrient solutions (above $50 \mu \mathrm{mol} \mathrm{L}^{-1}$ ) caused a reduction in the growth of the aerial parts and roots of aroeira (Schinus terebinthifolius Raddi) and tomato plants. MEHRABAN et al. (2008) also verified that Fe doses above $50 \mathrm{mgL}^{-1}$ hampered the development of the root system of rice plants, because the excess of this micronutrient increased lipid peroxidation. According to DORLODOT et al. (2005) this causes a reduction in the volume of roots and hinders the formation of root hairs; thus, interfering with the absorption of water and nutrients by the plant.

Concentration of total chlorophyll did not differ in response to $\mathrm{Fe}$ doses applied in the substrate, with an average of $8.80 \mathrm{mg}$ L-1(Figure 1e). Visual symptoms of deficiency or toxicity caused by the lack or excess of $\mathrm{Fe}$ were not observed. In both situations chlorosis is usually observed (EPSTEIN \& BLOOM, 2004), because according to BRIAT et al. (2007) Fe is linked to the formation of the heme groups, essential for the synthesis of chlorophylls. Thus, probably the Fe doses used in this study did not cause physiological alterations influencing the total content of chlorophyll in the leaves of rosebushes.

The Fe foliar levels increased linearly with the application of Fe doses in the substrate. The more the Fe applied to the substrate, the higher were the levels of this element in the leaves, reaching levels around $115 \mathrm{mg} \mathrm{kg}^{-1}$ at the highest Fe dose (Figure 1f). The Fe foliar content of the plants that did not receive application of this element was $58.5 \mathrm{mg} \mathrm{kg}^{-1}$. This levels is below and all the others are within the range of levels considered adequate for the production of roses according to MARTINEZ et al. (1999) which are 60$200 \mathrm{mg} \mathrm{kg}^{-1}$. VILLAS BÔAS et al. (2008) evaluated the absorption of nutrients for twelve rosebush cultivars in the field and also verified that there was a difference between them, being $\mathrm{Fe}$ more uptaken than $\mathrm{Mn}$ in seven cultivars. Also KHOSHGOFTARMANESH et al. (2008), evaluating the $\mathrm{Fe}$ application alone and in association with $\mathrm{Cu}, \mathrm{Zn}$ and $\mathrm{Mn}$ in rosebush cultivars, have verified varietal differences compared to the accumulation of Fe. Two of the three cultivars 


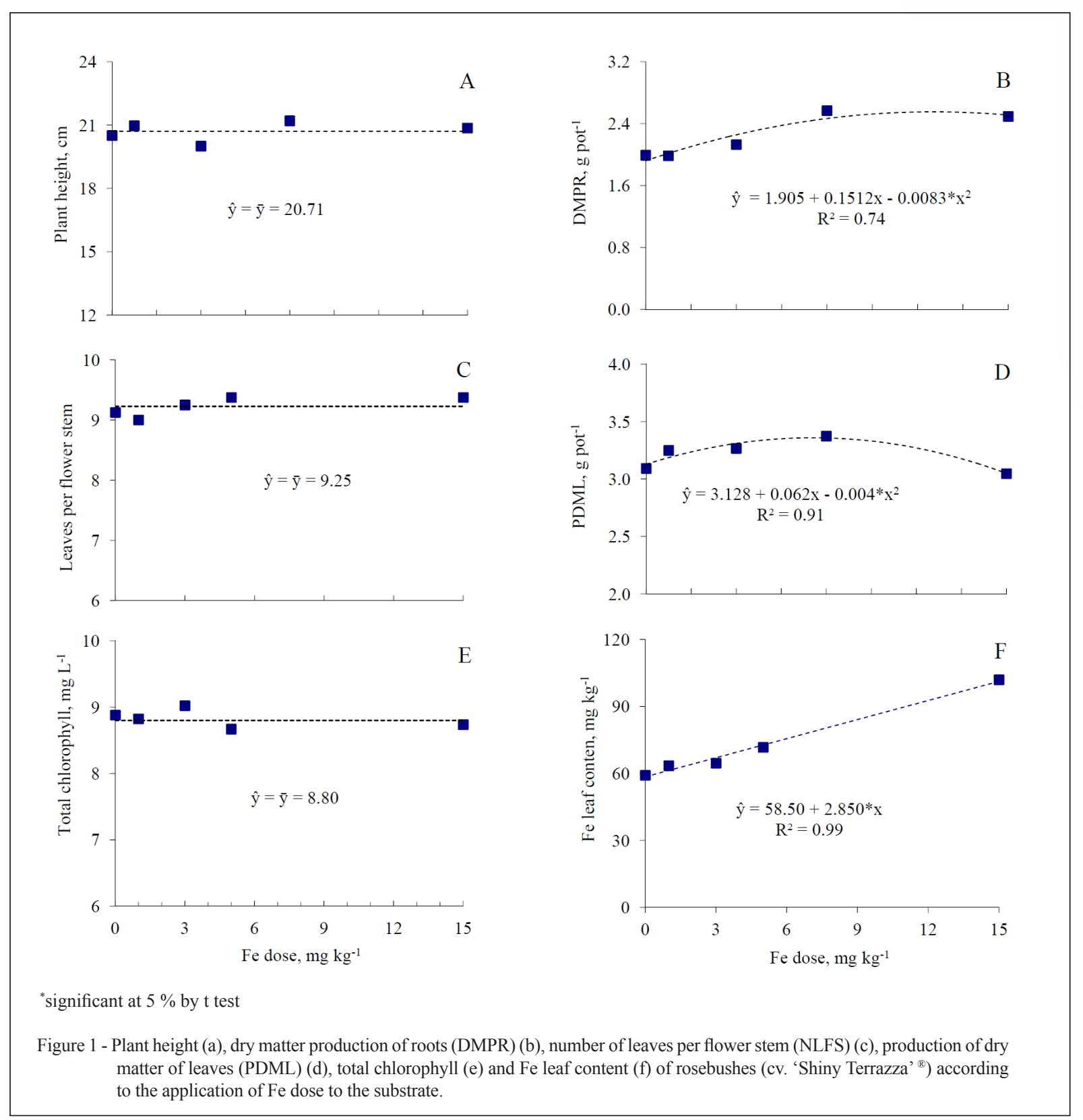

analyzed presented an increase in Fe foliar levels when this nutrient was added while in the third one this increase was not observed. The results also depended on the combination of $\mathrm{Fe}$ with other micronutrients.

The diameter of the flowers was influenced by the Fe doses applied, according to a quadratic model. The greatest floral diameter of $8.8 \mathrm{~cm}$ was achieved at a dose of $8.15 \mathrm{mg} \mathrm{kg}^{-1}$ Fe (Figure 2a). AHMAD et al. (2010) have also verified increase in the floral diameter of three varieties of rosebushes following foliar application of $\mathrm{Fe}$ as compared to the control. Floral diameter is a characteristic that is taken into account for the commercial classification of some species of ornamental plants.

The production of dry matter in flowers was significantly influenced by Fe doses and reached a maximum value of $1.52 \mathrm{~g} \mathrm{plant}^{-1}$ with a dose of $9.75 \mathrm{mg} \mathrm{kg}^{-1}$ (Figure 2b) and a production corresponding to maximum economic efficiency $\left(1.44 \mathrm{~g} \mathrm{plant}^{-1}\right)$ was obtained with the application of $3.6 \mathrm{mg} \mathrm{kg}^{-1} \mathrm{Fe}$. The good response of rosebushes to fertilization with $\mathrm{Fe}$ is mainly due to the fact that the substrate used presented low available Fe contents (around $0.1 \mathrm{mg} \mathrm{L}^{-1}$ ). Results of the present study indicated that the Fe application for rosebushes grown on substrates 


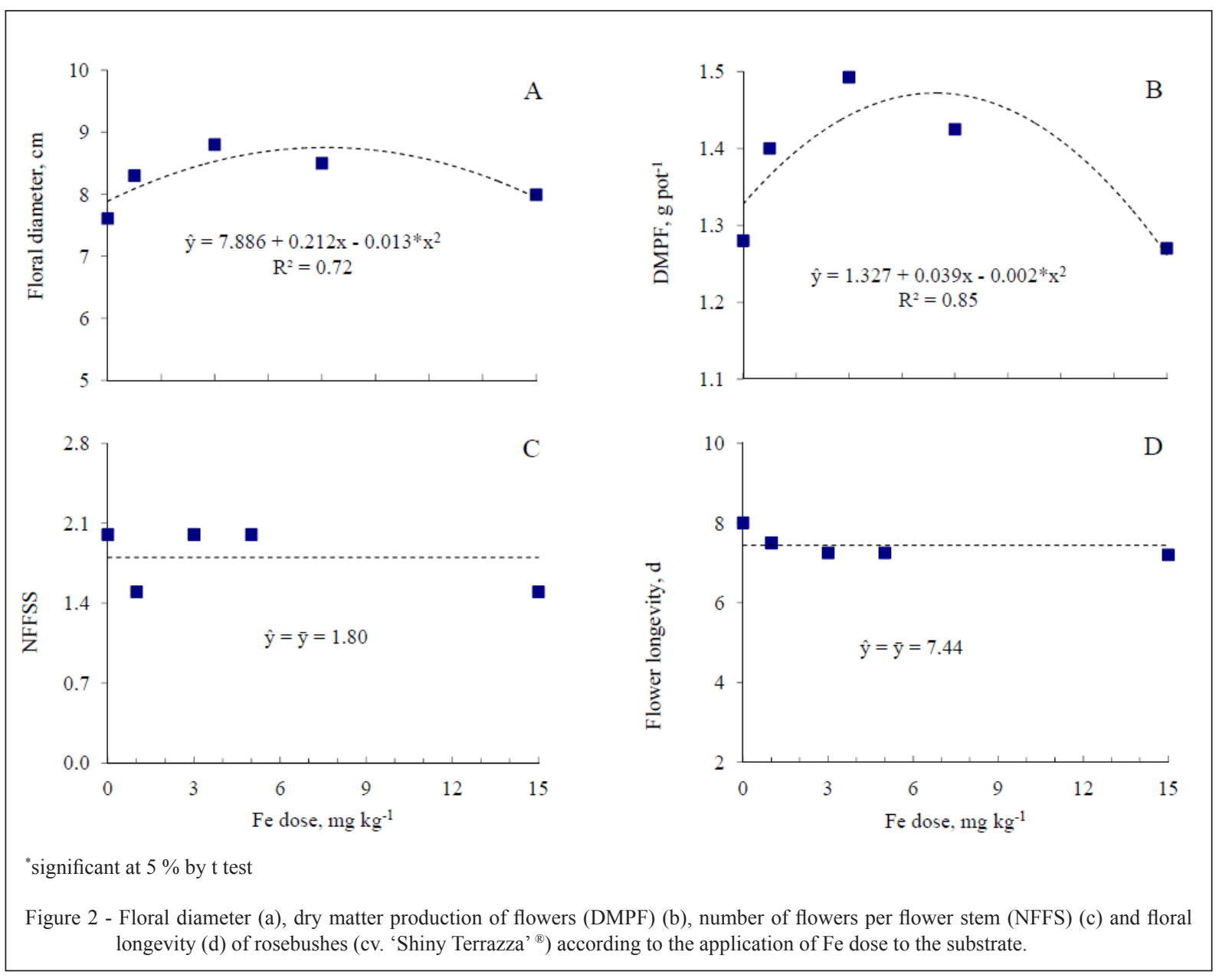

with low available Fe levels is important. Additions of Fe above $9.75 \mathrm{mg} \mathrm{kg}^{-1}$ caused a decrease in the production of dry matter in flowers.

Fe doses did not influence the number of flowers per floral stem and floral longevity (Figures $2 \mathrm{c}$ and $2 \mathrm{~d}$ ). On average, 1.85 flowers per flower stem were produced with longevity of 7.3 days. Similar results were obtained for this cultivar, by ZANÃO JÚNIOR et al. (2014), evaluating the application of different doses of B. AHMAD (2010), analyzing different cultivars of roses, obtained better results in the production of flowers per plant when applying $B$ and $\mathrm{Zn}$, while they also reported no effect of Fe doses on this variable. KHOSHGOFTARMANESH et al. (2008) verified that the addition of Fe to the substrate significantly increased the longevity of the roses of three cultivars, but only when this micronutrient was applied together with $\mathrm{Mn}+\mathrm{Zn}+\mathrm{Cu}$ or with $\mathrm{Mn}+\mathrm{Zn}$, suggesting an interaction between them.

\section{CONCLUSION}

Fertilization with $\mathrm{Fe}$ increases the production and quality of flowers of the rosebush cv. 'Shiny Terrazza' ${ }^{\circledR}$. The suggested dose of Fe to be added to the substrate used in this study for maximum economic efficiency for this cultivar is $3.6 \mathrm{mg} \mathrm{kg}^{-1}$.

\section{REFERÊNCIAS}

AHMAD, I. et al. Growth, yield and quality of Rosa hybrid L. as influenced by various micronutrients. Pakistan Journal of Agricultural Sciences, v.47, p.5-12, 2010. Available from: $<$ http:// pakjas.com.pk/papers/4.pdf>. Accessed: Oct. 25, 2015.

ALBANO, J. P.; MILLER, W. B. Ferric ethylenediamine-tetraacetic acid (FeEDTA) photodegradation in commercially produced soluble fertilizers. Horttechnology, v.11, p.265-267, 2001. Available from: <https://www.ars.usda.gov/ARSUserFiles/11847/ albano_miller_2001c.pdf $>$. Accessed: Jul. 25, 2016. 
ALVAREZ, V. V. H. Correlação e calibração de métodos de análise de solos. In: ALVAREZ V. et al. O solo nos grandes domínios morfoclimáticos do Brasil e o desenvolvimento sustentado.Viçosa, MG: SBCS/UFV/DPS, 1996. p. 615-646.

AREF, F. Manganese, iron and copper contents in leaves of maize plants (Zea mays L.) grown with different boron and zinc micronutrients. African Journal of Biotechnology, v.11, p.896-903, 2012. Available from: <http:// www.ajol.info/index.php/ajb/article/view/100222>. Accessed: Jun. 20, 2016. doi: 10.5897/AJB11.165.

BARGUIL, B. M. et al. Morphological and fitossanitary characteristics in rose varieties on classification stage. Ciência Rural, v.40, p.1545-1549, 2010. Available from: $<$ http://www.scielo.br/scielo.php?script=sci_artte xt\&pid $=$ S0103-84782010000700010 $>$. Accessed: May. 01, 2016. doi: 10.1590/S0103-84782010005000121.

BRIAT, J. F. et al. Iron utilization and metabolism in plants. Current Opinion in Plant Biology, v.10, p.276-282, 2007. Available from: $<$ https://www.ncbi.nlm.nih.gov/pubmed/17434791>. Accessed: Aug. 20, 2016. doi: 10.1016/j.pbi.2007.04.003.

CUSHMAN, L. C. et al. Cultivar, flower stage, silver thiosulfate and BA interactions affect performance of potted miniature roses. Hort Science, v.29, p.805-808, 1994. Available from: <http://hortsci.ashspublications. org/content/29/7/805.full.pdf>. Accessed: Jan. 25, 2016.

DUTRA, A. V. Nutrição e produção de rosas de corte, cultivares "Vegas" e "Tineke". 2009. 94f. Tese (Doutorado em Agronomia) - Universidade de São Paulo Escola Superior de Agricultura "Luiz de Queiroz - Piracicaba, SP.

DORLODOT, S. et al. Effects of ferrous iron toxicity on the growth and mineral composition of and interspecific rice. Journal of Plant Nutrition, v.28, p.1-20, 2005. Available from: <http://www.tandfonline.com/doi/ abs/10.1081/PLN-200042144> $>$. Accessed: Oct. 25, 2016. doi: 10.1081/PLN200042144.

EPSTEIN, E.; BLOOM, A. J. Mineral nutrition of plants: principles and perspectives. 2. ed. Sunderland: Sinauers Associates, 2004. 200p.

FAGERIA, N. K.; BARBOSA FILHO, M. P. Identificação e correção de deficiências nutricionais na cultura do arroz. Brasília: Embrapa, 2006. 8p. (Circular técnica n.75).

FURTINI NETO, A. E. et al. Nutrition and quality in ornamental plants. Ornamental Horticulture, v.21, p.139-150, 2015. Available from: <https://ornamentalhorticulture.emnuvens.com.br/rbho/article/ view/809/570>. Accessed: Feb. 10, 2016. doi: 10.14295/aohl.v21i2.809.

INSTITUTO BRASILEIRO DE FLORICULTURA. Dados do setor condensado 09. 2015. Available from: $<$ http://www.ibraflor. com/publicacoes/vw.php?cod=246>. Accessed: Nov. 30, 2015.

JONES JÚNIOR, J. B. et al. Plant analysis handbook. Athens, Georgia: Micro-Macro Publishing. 1991. 213p.

JUNQUEIRA, A. H.; PEETZ, M. S. The productive sector of flowers and ornamental plants of Brazil, in the period from 2008 to 2013: updates, balance sheets and prospects. Revista Brasileira de Horticultura Ornamental, v.20, p.115-120, 2014. Available from: $<$ http://www.uesb.br/flower/florbrasil.pdf>. Accessed: Mar. 23, 2016. doi: 10.14295/rbho.v20i2.727.

KAMBLE, B. M. et al. Effect of iron on yield of turmeric (Curcuma longa ) in Maharashtra, India. International Journal of Bio-resource and Stress Management, v.5, p. 502-506, 2014. Available from: $<$ http://www.pphouse.org/admin/uploadpdf/6AR696_Kamble\%20 et\%20al.pdf>. Accessed: Dec. 29, 2015. doi: 10.5958/09764038.2014.006058.

KHOSHGOFTARMANESH, A. H. et al. Influence of additional micronutrient supply on growth, nutritional status and flower quality of three rose cultivars in a soilless culture. Journal of Plant Nutrition, v.31, p.1543-1554, 2008. Available from: <http://www.tandfonline. com/doi/abs/10.1080/01904160802244662?journalCode=lpla20 >. Accessed: Feb. 21, 2016. doi: 10.1080/01904160802244662.

MARTINS, M. V. M. et al. Produção integrada de flores no Brasil. Informe Agropecuário, v. 30,p.64-66,2009. Available from: $<$ https://www.embrapa. br/agroindustria-tropical/busca-de-publicacoes/-/publicacao/575202/ producao-integrada-de-flores $>$. Accessed: Jan. 24, 2016.

MEHRABAN, P. et al. Iron toxicity in rice (Oryza sativa L.) under different potassium nutrition. Asian Journal of Plant Sciences, v.7, p.251-259, 2008. Available from: <http://www.docsdrive.com/ pdfs/ansinet/ajps/2008/251-259.pdf $>$. Accessed: Oct. 25, 2015. doi: 0.3923/ajps.2008.251.259.

PORRA, R. J. et al. Determination of accurate extinction coefficients and simultaneous equations for assaying chlorophylls a and b extracted with four different solvents: verification of the concentration of chlorophyll standards by atomic absorption spectrometry. Biochimica et Biophysica Acta, v.975, p.384-394, 1989. Available from: <http:// www.sciencedirect.com/science/article/pii/S0005272889803470>. Accessed: Oct. 25, 2015. doi: 10.1016/S0005-2728(89)80347-0.

SANTOS, T. C. et al. Initial growth of aroeira (Schinus terebinthifolius Raddi) and tomato transgenic AVP1OX (Solanum lycopersicum L.) in different levels of iron. Natureza online, v.9, p.152-156, 2011. Available from: <http://www.naturezaonline.com. br/natureza/conteudo/pdf/11_santostcetal_152_156.pdf $>$. Accessed: Aug. 22, 2015.

SAVVAS, D. General introduction. In: SAVVAS, D.; PASSAM, H.C. (Eds.). Hydroponic production of vegetables and ornamentals. Athens, Greece: Embryo Publications, 2002. p.15-23.

SONNEVELD C.; ELDEREN C. W. Chemical analysis of peaty growing media by means of water extraction. Communication on Soil Science and Plant Analysis, v.25, p.3199-3208, 1994. Available from: $<$ http://www.tandfonline.com/doi/abs/10.1080/00103629409369258>. Accessed: Jan., Oct. 22, 2016. doi: 10.1080/00103629409369258.

TAIZ, L.; ZEIGER, E. Plant physiology. 5.ed. Sunderland: Sinauer Associates, 2010. 782 p.

VILLAS BÔAS, R. L. et al. Nutrients exportation and the quality of rose cultivars in field and in a protected environment. Horticultura Brasileira, v.26, p.515-519, 2008. Available from: $<$ http://www.scielo.br/pdf/hb/v26n4/v26n4a18.pdf $>$. Accessed: Oct. 25, 2016. doi: 10.1590/S0102-05362008000400018.

ZANÃO JÚNIOR, L. A. et al. Rose production affected by silicon rates applied to substrate. Revista Brasileira de Ciência do Solo, v.37, p.1611-1619, 2013. Available from: $<$ http://www.scielo.br/scielo. php?script=sci_arttext\&pid=S0100-06832013000600017>. Accessed: Oct. 11, 2015. doi: 10.1590/S0100-06832013000600017.

ZANÃO JÚNIOR, L. A. et al. Production and quality of roses as affected by boron fertilization. Revista Brasileira de Ciência do Solo, v.38, p.524-531, 2014. Available from: <http://www.scielo.br/scielo. php?script=sci_arttext\&pid=S0100-06832014000200017>. Accessed: Feb. 23, 2016. doi: 10.1590/S0100-06832014000200017. 